\title{
Molecular characterization and evaluation of crude oil remediation potential of some rhizobia isolated from plant root nodules
}

\author{
Jesupemi Mercy Enibukun ${ }^{\bowtie}$ and Bolatito Esther Boboye \\ Department of Microbiology, Federal University of Technology, PMB 704, Akure, Ondo state, Nigeria
}

\section{Article info}

Article history:

Received: $6^{\text {th }}$ February 2020

Accepted: $2^{\text {nd }}$ May 2020

\section{Keywords:}

Bioremediation

Cajanus cajan

Crude oil pollution

Molecular characterization

Phaseolus vulgaris

Rhizobia

\begin{abstract}
This study aimed to determine the molecular identities and genetic relatedness of rhizobia isolated from pigeon pea and pinto beans, and assess their remediation potential in the presence of $1 \%, 3 \%$ and $5 \%(\mathrm{w} / \mathrm{v})$ crude oil in minimal medium for 7 days incubation period. Standard microbiological and molecular methods which include amplification and purification of $16 \mathrm{~S}$ rRNA, agarose gel electrophoresis, and sequencing. Results showed molecular identities of six rhizobia from pigeon peas as Bradyrhizobium diazoefficiens USDA122, Rhizobium leguminosarum WSM2304, $B$. japonicum N61, $R$. leguminosarum N741, R. leguminosarum BIHIB1217, and B. japonicum E109; and three rhizobia obtained from pinto beans were $R$. leguminosarum N871, B. diazoefficiens USDA110 and B. japonicum SEMIA5079. All tested rhizobia (9) showed petroleum degradation ability, as they all grew in the 1,3 and $5 \%(\mathrm{w} / \mathrm{v})$ crude oil minimal medium under laboratory conditions. B. diazoefficiens USDA122 showed the highest optical density (OD) value of $1.184 \pm 0.05$ on $7^{\text {th }}$ day at $1 \%(\mathrm{w} / \mathrm{v})$ crude oil contamination, while $R$. leguminosarum N741 has the lowest OD value of $0.372 \pm 0.02$ at $5 \%(\mathrm{w} / \mathrm{v})$ crude oil on $7^{\text {th }}$ day. For all the rhizobia, increase occurred throughout incubation period at 1,3 and $5 \%$ (w/v) except $R$. leguminosarum N741 and $R$. leguminosarum BIHIB1217. In conclusion, the association of $R$. leguminosarum BIHIB1217 and $R$. leguminosarum $\mathrm{N} 871$ from pigeon pea and pinto beans respectively, were found most effective in crude oil degradation and thus they are recommended as a promising association for remediation of crude oil spilled soils.
\end{abstract}

(c) University of SS. Cyril and Methodius in Trnava

\section{Introduction}

The ability of humans to change the environment has increased faster than the ability to predict the effect of that change (Ikuesan 2015). Pollution of the environment is one of the major effects of human technological advancement. Pollution can be defined as the introduction of deleterious substance into the environment that endangers human health and other natural resources (Onojake 2004). It results when a change in the environment harmfully affects the quality of human life and other essential living things such on animals, microorganisms and plants (Ogbogbodo et al. 2005; Eremrena and Akonye 2013).

Crude oil is a naturally occurring complex mixture of thousands of hydrocarbons and non-hydrocarbon compounds, including heavy metals. Organic chemicals such as hydrocarbons are major constituents of petroleum, which can enter the aquatic environment through natural and anthropogenic sources (Daniel and Nna 2016). Total petroleum hydrocarbon ( $\mathrm{PHC}$ ) is a mixture of measurable number of petroleum-based 
hydrocarbons found in crude oil in an environmental media (Rauckyte et al. 2010). Some of the chemicals found in TPH are hexane, benzene, toluene, xylene, naphthalene as well as other petroleum products and gasoline components. Crude oil contamination constitutes one of the most prevalent sources of environmental pollution due to variation in chemical composition of crude oil and its products degradation in the industrialized world (Mandal et al. 2012). Crude oil pollution can be defined as the introduction of crude oil or its derivatives with its associated gases into the environment (air, water and land) in quantities that are poisonous or capable of causing immediate physical, chemical and biological damages to the affected ecosystem (Lee et al. 2001; Inoni 2006; Tanee and Anyanwu 2007; Nyananyo 2008; Tanee and Akonye 2009). Petroleum industry's effluents, oily sludge and oil spills cause a serious threat to the environment as their constituents are toxic, mutagenic and carcinogenic (Nyananyo 2008; Wokoma 2014; Ataikiru et al. 2018).

The remediation of oil contaminated soils has been a major problem in oil producing countries and recently use of plants to clean such soils has been investigated. Several methods such as physical and chemical means have been adopted in remediation of hydrocarbon polluted soil or the detoxification of hazardous substances (Diplock et al. 2009). However, these methods were not effective in the total recovery of polluted soils. Phytoremediation and bioaugmentation engage the process of converting organic waste into an innocuous state by the use of plants and microbes respectively. Due to the abilities of certain microbes to mineralize hydrocarbon components into environmentally friendly substances such as carbon dioxide and water, the ability of bacteria in breaking down hydrocarbons has gained growing attention in modern day research (Kadali et al. 2012; Gkorezis et al. 2016). The degradative activity of bacteria isolated from hydrocarbon polluted soil has been investigated by monitoring the changes in optical density (OD) which was directly proportional to the activity (Boboye et al. 2010). There is premise that the genome of these organisms, harbour genes or enzymes responsible for the degradation (Gkorezis et al. 2016).

Legumes belong to the family Fabaceae or Leguminosae. Legumes are plants that form symbiotic association with rhizobia in the symbiosis legumes nitrogen fixing root or stem nodules. Legumes include cowpea, soybean, pigeon peas, pinto beans, alfalfa, chicken peas, lentils, peanut and lupin beans (Ismail et al. 2014). Cajanus cajan (L.) which commonly called pigeon pea, red gram, congo pea, or gungo pea, is one of the most common legumes cultivated in the tropics and subtropics, for its edible seed (Fig. 1). It is a legume domesticated majorly in the India
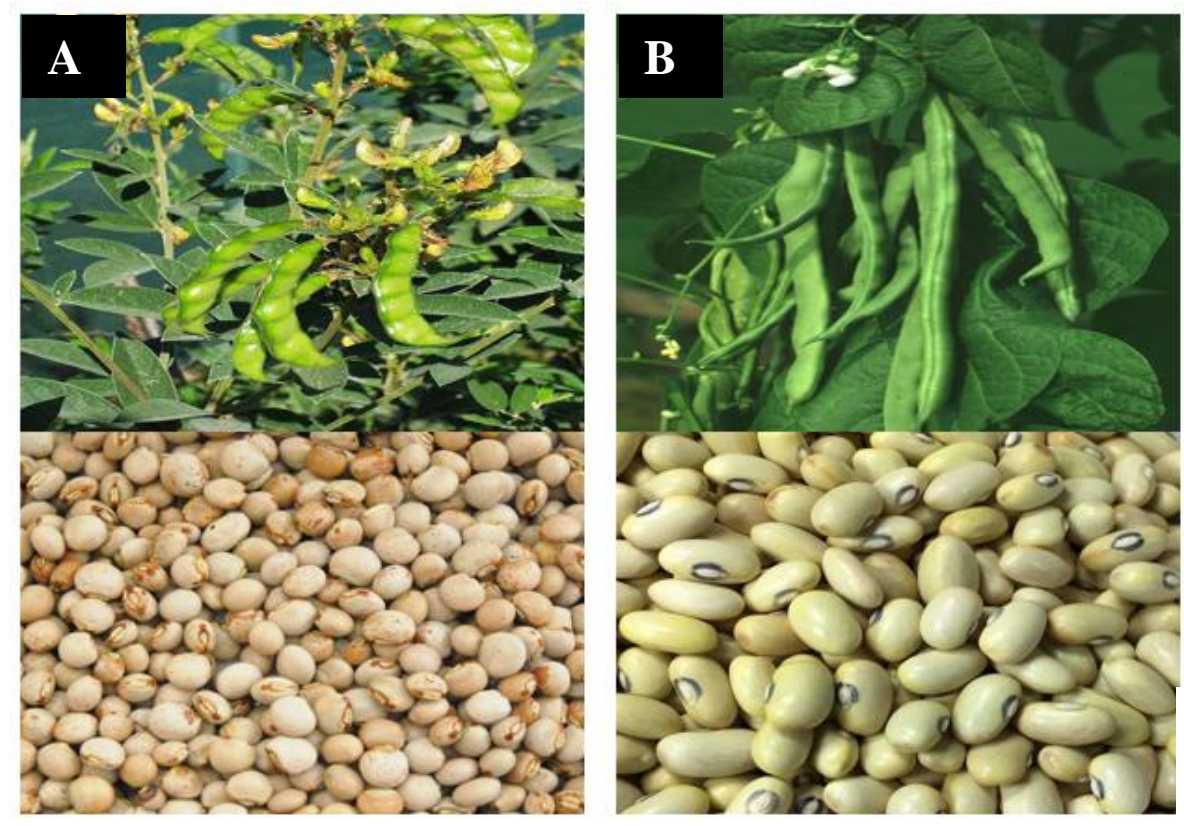

Fig. 1. The plant and seed of (A) pigeon pea (Cajanus cajan) and (B) pinto beans (Phaseolus vulgaris). 
and North-eastern Africa in over 3,000 years ago (Mallikarjuna et al. 2011). Pigeon pea is found useful in many areas as growth enhancer, alley crop, and protein and trace nutrient supplement, control of weeds and nematodes as well as medication (Odeny 2007). The pinto beans (Phaseolus vulgaris) are legumes referred to as common beans (Fig. 1), they spread throughout South and Central America, Europe, Africa and Asia (Rodino et al. 2001). Pinto beans are the most highly consumed dried bean in the United States. Its protein content is comparable with those in other legumes like cowpea and groundnut which had been used in complementing maize diet rich in mineral and fibre.

Legumes are known to have an advantage over non-leguminous plants in phytoremediation because of their ability to fix nitrogen and thus, do not have to compete with microorganisms and other plants for limited supplies of available soil nitrogen at oil-contaminated sites (Cameron 2003). The root nodule symbiosis established between legumes and rhizobia is an exquisite biological interaction responsible for fixing a significant amount of nitrogen in terrestrial ecosystems. The success of this interaction depends on the recognition of the right partner by the plant within the richest microbial ecosystems on earth, the soil. The economic and ecological importance of legumes is evidenced by the high number of species that are cultivated and commercialized, as well as by their ability to obtain nitrogen from a symbiotic interaction with soil bacteria known as rhizobia (Oberai and Khanna 2018).

Plant-microbial interactions will be better understood by considering the organism in its natural environment together with its microbiome (Thijs et al. 2016). 16S rRNA gene sequencing is a well-utilized method for nucleic acid-based detection and identification of microbes, their taxonomic assignment, phylogenetic analysis and the study of microbial diversity (Quast et al. 2013). The objective of this study was to isolate and determine the molecular identities and phylogenetics of some tropical rhizobia from pigeon pea and pinto beans, and assess the crude oil degradative ability of these isolated rhizobia. Since nitrogen act as alternative to chemical fertilizers, the study of the crude oil bioremediation potential of rhizobia-legume association will provide strategy for farming on polluted agricultural soil.

\section{Experimental}

\section{Source of legumes}

Pigeon pea (Cajanus cajanus) and pinto beans (Phaseolus vulgaris) legumes were sourced from Oba market, Akure, Nigeria. The legumes were identified and authenticated at the Department of Crop, Soil and Pest management (CSP) of the Federal University of Technology, Akure, Nigeria.

\section{Materials, media and reagents}

All reagents used in this study were of analytical and microbiological standard. Nutrient agar (NA) composed of: meat extract $\left(1\right.$ g. $\left.\mathrm{L}^{-1}\right)$; peptone (5 g. $\left.\mathrm{L}^{-1}\right)$; yeast extract $\left(2\right.$ g. $\left.\mathrm{L}^{-1}\right)$; sodium chloride (8 g.L $\left.\mathrm{L}^{-1}\right)$; agar $\left(15\right.$ g. $\left.\mathrm{L}^{-1}\right)$; and distilled water $(1 \mathrm{~L})$, at $\mathrm{pH}$ 6.8. Mineral Salt Medium (MSM) composed of $\left(\mathrm{g} . \mathrm{L}^{-1}\right): 1 \mathrm{~g} \mathrm{NaCl}, 1 \mathrm{~g} \mathrm{KH}_{2} \mathrm{PO}_{4}, 1 \mathrm{~g} \mathrm{Na}_{2} \mathrm{HPO}_{4}$, $\begin{array}{lllllll}0.5 \mathrm{~g} & \mathrm{NH}_{4} \mathrm{NH}_{3}, & 0.5 & \mathrm{~g} & \left(\mathrm{NH}_{4}\right)_{2} \mathrm{SO}_{4}, & 0.2 \mathrm{~g}\end{array}$ $\mathrm{MgSO}_{4} .7 \mathrm{H}_{2} \mathrm{O}, 0.02 \mathrm{~g} \mathrm{CaCl}_{2} .2 \mathrm{H}_{2} \mathrm{O}, 0.002 \mathrm{~g} \mathrm{FeCl}_{3}$, and $0.002 \mathrm{~g} \mathrm{MnSO}_{4} .2 \mathrm{H}_{2} \mathrm{O}$ in 1.0 litre of distilled water, at $\mathrm{pH} 7.0$ and sterilizes at $121{ }^{\circ} \mathrm{C}$ for $15 \mathrm{~min}$ by autoclave. Modified Mineral Salt Medium (MMSM) consisted of $\left(\mathrm{g} . \mathrm{L}^{-1}\right): 4 \mathrm{~g} \mathrm{KH}_{2} \mathrm{PO}_{4}, 4 \mathrm{~g}$ $\mathrm{NH}_{4} \mathrm{NH}_{3}, \quad 0.2 \mathrm{~g} \quad \mathrm{MgSO}_{4} .7 \mathrm{H}_{2} \mathrm{O}$, and $0.01 \mathrm{~g}$ $\mathrm{CaCl}_{2} .2 \mathrm{H}_{2} \mathrm{O}$, in $1.0 \mathrm{~L}$ of distilled water, at $\mathrm{pH} 7.0$ and sterilized at $121{ }^{\circ} \mathrm{C}$ for $15 \mathrm{~min}$ by autoclave. MSM was used for growth of isolated mutants that is used in this experiment while MMSM was used to encourage oil emulsion process which leads to oil degradation.

\section{Isolation of Rhizobium from legumes and cultivation of test bacteria}

Surface sterilization of the seeds were done with $3.5 \% \quad(\mathrm{w} / \mathrm{v})$ sodium hypochlorite solution for $15 \mathrm{~min}$ and rinsed in sterile distilled water. The seeds were transferred into sterile sandy soil in different sterilized plant jar, regularly wet with MMSM and allowed to germinate at $28 \pm 2{ }^{\circ} \mathrm{C}$ (daytime) for 90 days in a locally-made greenhouse facility. The root nodules of the germinated plants were used respectively. The root aggregates were 
collected and sterilized using $3.5 \% \quad(\mathrm{v} / \mathrm{v})$ hypochlorite solution, sterile root was crushed with tweezers, then the root nodule extracts were grown on nutrient agar, incubated at room temperature $\left(28{ }^{\circ} \mathrm{C}\right)$ for 24 hours. Bacterial colonies were gram stained by method of Fawole and Oso (2007); the bacterial cells that retained the purple stain from the crystal-violet staining were referred to as Gram positive and those that showed pink from the safranin staining were referred to as Gram negative. Each was cultured in nutrient broth overnight at $30{ }^{\circ} \mathrm{C}$ until log phase (optical density at $600 \mathrm{~nm}$ ) and used for molecular characterization.

\section{Identification and molecular characterization of bacterial isolates}

Total DNA was extracted from $2 \mathrm{~mL}$ of each grown bacterium. The cells were pelleted by centrifuging at 12,000 rpm for $2 \mathrm{~min}$. The pellet was mixed with TRIS-EDTA (TE) buffer and treated with sodium dodecyl sulphate for $10 \mathrm{~min}$. Isopropanol $(600 \mu \mathrm{L})$ was added and centrifuged at $10,000 \mathrm{rpm}$ for $10 \mathrm{~min}$ and decanted. The pellet formed was dissolved in $0.1 \mathrm{~mL}$ of a TE buffer. The DNA was quantified using Nanodrop machine at $260 \mathrm{~nm}$ and $280 \mathrm{~nm}$. The 16S rRNA gene was amplified using primers: (i) 5' AGAGTTTGATCCTGGCTCAG 3' and (ii) 5' GACGGGCRGTGWGTRCA 3'. The polymerase chain reaction (PCR) mix contained 10X buffer, $100 \mathrm{mM}$ dNTPs, $2.52 \mathrm{M}$ $\mathrm{MgCl}_{2}$, 2U Taq DNA polymerase, $1.0 \mu \mathrm{L}$ of each primers, $2.0 \mu \mathrm{L}$ of the extracted DNA and sterilized distilled water to make a final volume of $25 \mathrm{~mL}$. The mixture was subjected to amplification on PCR machine with the following parameters: initial $94{ }^{\circ} \mathrm{C} 3 \mathrm{~min}$, followed by 25 cycles run in a thermal cycler, each comprising of $1 \mathrm{~min}$ at $94{ }^{\circ} \mathrm{C}, 1 \mathrm{~min}$ at $94{ }^{\circ} \mathrm{C}$ and $1.5 \mathrm{~min}$ at $94{ }^{\circ} \mathrm{C}$. The final denaturation was at $94{ }^{\circ} \mathrm{C}$ for $10 \mathrm{~min}$. About $2.0 \mu \mathrm{L}$ of the PCR product was subjected to $1.0 \%(\mathrm{w} / \mathrm{v})$ agarose-gel electrophoresis at $90 \mathrm{~V}$ for about $30 \mathrm{~min}$, and the resulted gel was observed under UV transilluminator and photographed. $1 \mu \mathrm{L}$ of the amplified DNA was sequenced on the Applied Biosystems Genetic Analyzer at facility in International Institute of Tropical Agriculture (IITA), Ibadan Nigeria. The DNA sequence of the PCR product of the 16S rRNA gene of each bacterium was subjected to homology analysis using BLASTN program of the National Center for Biotechnology Information (NCBI).

\section{Preparation of bacterial inoculum}

Nine rhizobia that grew equal to and above 0.600 optical density in the presence of crude oil at the end of the 7 days evaluation experiment on crude oil degradative capability were used. The rhizobia were inoculated into $5 \mathrm{~mL}$ nutrient broth and incubated at $28{ }^{\circ} \mathrm{C}$ for $24 \mathrm{~h}$. It was centrifuged at 4,000 rpm for $5 \mathrm{~min}$. The cells were re-suspended in $5 \mathrm{~mL}$ sterile distilled water. This constituted the bacterial inoculum.

\section{Evaluation of crude oil degradative capability of the test bacteria}

The mineral salt medium (Bushnell-Hass) was prepared. The medium was allowed to cool and crude oil was sterilized using $0.45 \mu \mathrm{m}$ Millipore filter and added to make final crude oil concentration of $1 \%, 3 \%$ and $5 \%$ volumes of 1,3 and $5 \mathrm{~mL}$. Uninoculated MSM broth containing the crude oil served as the control. The broth was inoculated with each Rhizobium species and incubated at $28 \pm 2{ }^{\circ} \mathrm{C}$ for 7 days. Culture tubes were agitated at $4,000 \mathrm{rpm}$ daily using shaking incubator to provide adequate oxygen for the bacteria to grow. During the incubation the optical density of each cultured rhizobium was read daily with spectrophotometer at $600 \mathrm{~nm}$ (Boboye et al. 2010).

\section{Statistical Analysis}

The data were taken in triplicates and expressed as mean \pm standard deviation (SD) using Microsoft Excel.

\section{Results}

The concentration of DNA from rhizobia samples ranged between 186.6 to 277.6 ng. $\mu \mathrm{L}^{-1}$. The 260/280 ranged between 1.81 to 1.97 , and indicated the quality of DNA of all the rhizobia were good. The 16S rRNA fragment was amplified by PCR on DNA from rhizobia. Gel separation 


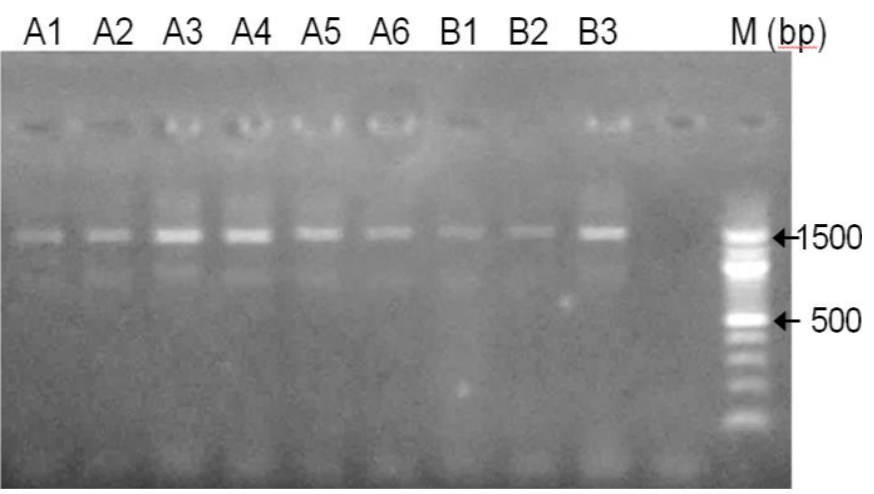

Fig. 2. The PCR products amplified on $16 \mathrm{~S}$ rRNA gene of rhizobia isolated from pigeon pea (isolates A1-A6) and pinto bean (isolates B1-B3). Lane $\mathrm{M}$ represents the DNA ladder.

confirmed the presence of a $1500 \mathrm{bp}$ fragment (Fig. 2). Arrangement of the nucleotides in the PCR product from the DNA extracted from each of the rhizobia isolated from pigeon pea and pinto beans. The number of each base in the total nucleotides in each rhizobium varied from one test bacterium to the other with total nucleotides ranging from A1 to A6 (403 to 551) bases for bacterium isolated from pigeon pea. The molecular identities of the bacteria isolated from pigeon pea and pinto beans are shown in Table 1. Among the bacteria isolated from pigeon pea were three species Bradyrhizobium and three species of Rhizobium. In pigeon pea, the percentage identity was lowest for isolate coded A6 $(96 \%)$ and highest (100\%) for bacteria A1, A, A3, and A5. The molecular identities of the bacteria associated with pinto beans were two species of Bradyrhizobium and one species of Rhizobium. The percentage identity for the bacteria isolated was the lowest for isolate B2 (99\%) and highest (100\%) for B1 and B3.

The phylogenetic tree (Fig. 3) shows the

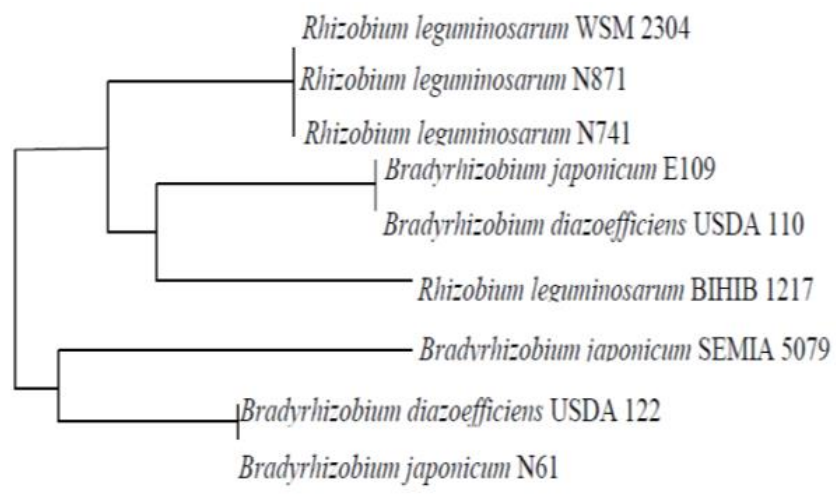

Fig. 3. A phylogenetic tree of the crude oil degrading rhizobia identified by molecular analysis.

relatedness of the bacteria isolated from pigeon pea and pinto beans. The phylogenetic tree of the isolate has three clades. From the first clade, there are three strains of Rhizobium leguminisarum (WSM2304, N871, and N741) which are closely related. In the second clade Bradyrhizobium japonicum E109 is closely related to Bradyrhizobium diazoefficiens USDA 110 than Rhizobium leguminisarum BIHB 1217 but shares the same ancestors. Bradyrhizobium diazoefficiens USDA 122 and Bradyrhizobium japonicum SEMIA5079 are closely related but shares a distance relationship with the other identified rhizobia Bradyrhizobium japonicum N61 in the third clade.

We studied the ability of the test rhizobia to grow in the presence of crude oil, supplied to growth media at concentrations $1 \%, 3 \%$ and $5 \%(\mathrm{v} / \mathrm{v})$. The OD values were taken as measure of growth thus crude oil degradation. Our data showed that crude oil differently affected the growth of individual isolates from pigeon bean (Fig. 4) as well as from pinto beans (Fig. 5). Generally,

Table 1. Molecular identities of bacteria associated with pigeon pea and pinto beans.

\begin{tabular}{llrl}
\hline Rhizobia code & Identified bacteria & Identity [\%] & Accession number \\
\hline A1 & Bradyrhizobium diazoefficiens USDA122 & 100 & CP013127.1 \\
A2 & Rhizobium leguminosarum WSM2304 & 100 & CP01193.1 \\
A3 & Bradyrhizobium japonicum N61 & 100 & CP017637.1 \\
A4 & Rhizobium leguminisarum N741 & 99 & CP013595.1 \\
A5 & Rhizobium leguminosarum BIHIB 1217 & 100 & CP022665.1 \\
A6 & Bradyrhizobium japonicum E109 & 96 & CP010313.1 \\
B1 & Rhizobium leguminisarum N871 & 100 & CP013590.1 \\
B2 & Bradyrhizobium diazoefficiens USDA 110 & 99 & CP011360.1 \\
B3 & Bradyrhizobium japonicum SEMIA5079 & 100 & CP007569.1 \\
\hline
\end{tabular}

A1-A6 represent bacteria isolate from pigeon pea. B1-B3 represent bacteria isolate from pinto beans 

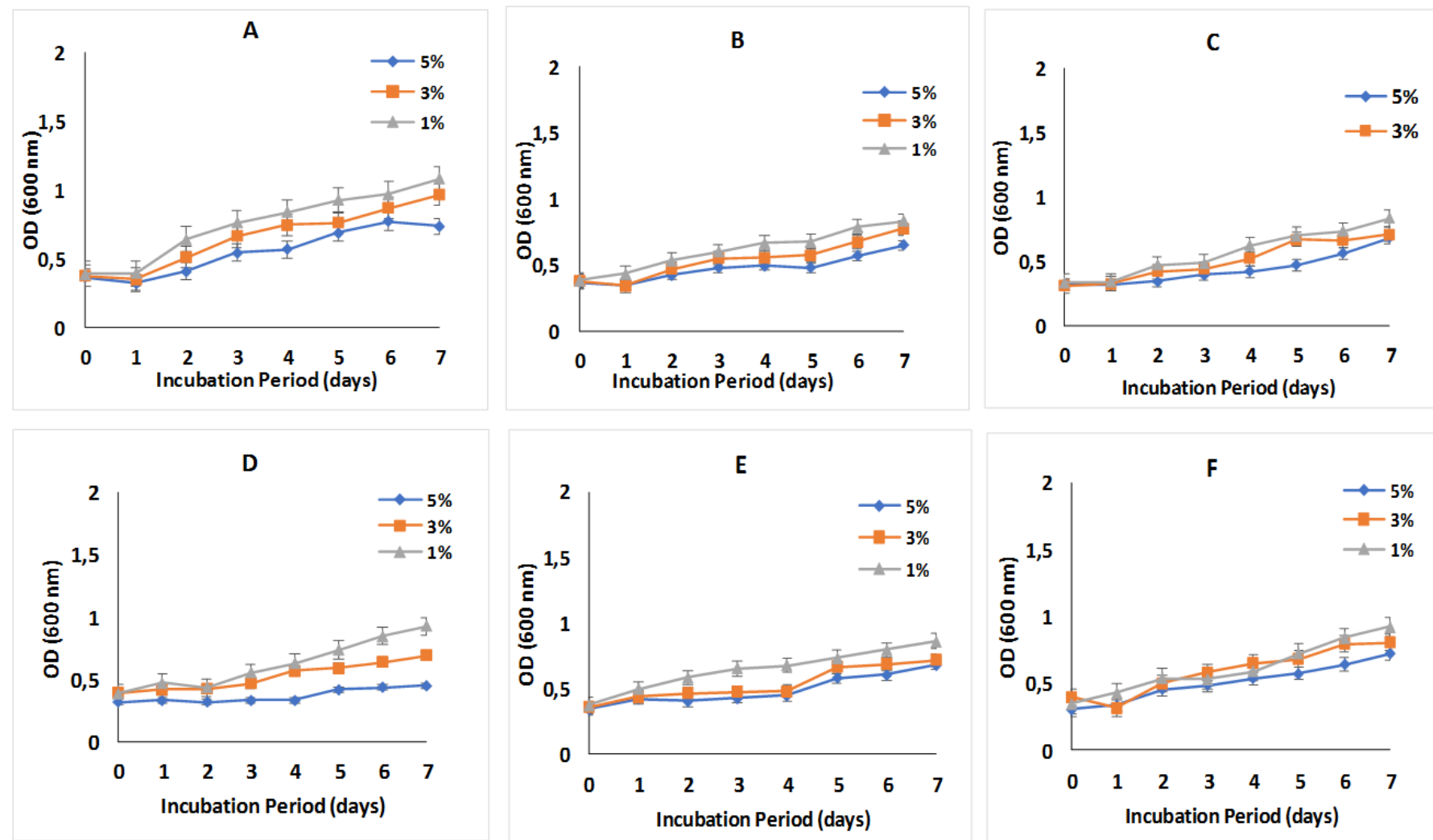

Fig. 4. Growth of test rhizobia isolated from pigeon pea in presence of crude oil in the medium $(1-5 \%$ w/v). Data represent means $\pm \mathrm{SD}(n=3)$. $\mathbf{A}=$ B. diazoefficiens USDA122; $\mathbf{B}=R$. leguminosarum WSM2304; $\mathbf{C}=$ B. japonicum N61; $\mathbf{D}=$ R. leguminosarum $\mathrm{N741} ; \mathbf{E}=$ R. leguminosarum BIHIB1217; $\mathbf{F}=$ B. japonicum $\mathrm{E} 109$.

addition of $1 \%(\mathrm{w} / \mathrm{v})$ crude oil promoted rhizobia growth the most, followed by $3 \%$ and $5 \%$ oil concentration (Fig. 4 and 5). The effect of oil was significant at $P<0.05$. Best growth was observed for $B$. diazoefficiens USDA122 at $1 \%$ (w/v) crude oil contamination (OD $1.184 \pm 0.05$ on $7^{\text {th }}$ day). In contrast, most inhibited was the growth of $R$. leguminosarum N741 (OD $0.372 \pm 0.02$ on $7^{\text {th }}$ day) by $5 \%(\mathrm{w} / \mathrm{v})$ crude oil in growth media. Relatively flat growth curve was obtained for the rhizobia isolate $B$. diazoefficiens USDA122 (Fig. 4A). Of the rhizobia isolated from pigeon pea plants, B. japonicum $\mathrm{E} 109$ had the highest growth rate $\left(O D 0.899 \pm 0.06\right.$ on $7^{\text {th }}$ day), while the lowest one was obtained for B. diazoefficiens USDA122 on day 6 (Fig. 4A and F).

Moreover, among the rhizobia isolated from pinto beans plants, B. japonicum SEMIA5079 had the highest OD $\left(1.107 \pm 0.05\right.$ on $7^{\text {th }}$ day $)$ when compared to the OD obtained for R. leguminosarum N871 (Fig. 5A and C). The increase in optical density of each test bacteria in the presence of crude oil indicates utilization of the oil for growth and degradation of the test hydrocarbon. The results of this study showed that each test bacteria could survive and utilize crude oil at the percentages investigated.

\section{Discussion}

In bacteria, 16S rDNA forms core conserved region with about 1,500 base pair. The region is employed for bacteria identification. This correlated with data obtained by Mohamed et al. (2014) that 16s rRNA region is involved in bacterial identification.

Studies have shown that endophytic bacteria have a better capacity to enhance petroleum hydrocarbon (PHC) phytoremediation than rhizosphere or soil bacteria (Weyens et al. 2010; Yousaf et al. 2011). Cultivable endophytic bacteria have been isolated from various plants species which include maize (Gutierrez-Zamora and Martinez-Romero 2001), wheat (Larran et al. 2002), sugar cane (Loiret et al. 2004), and Mimosa pudica (Pandey et al. 2005).

A molecular characterization study on endophytic 

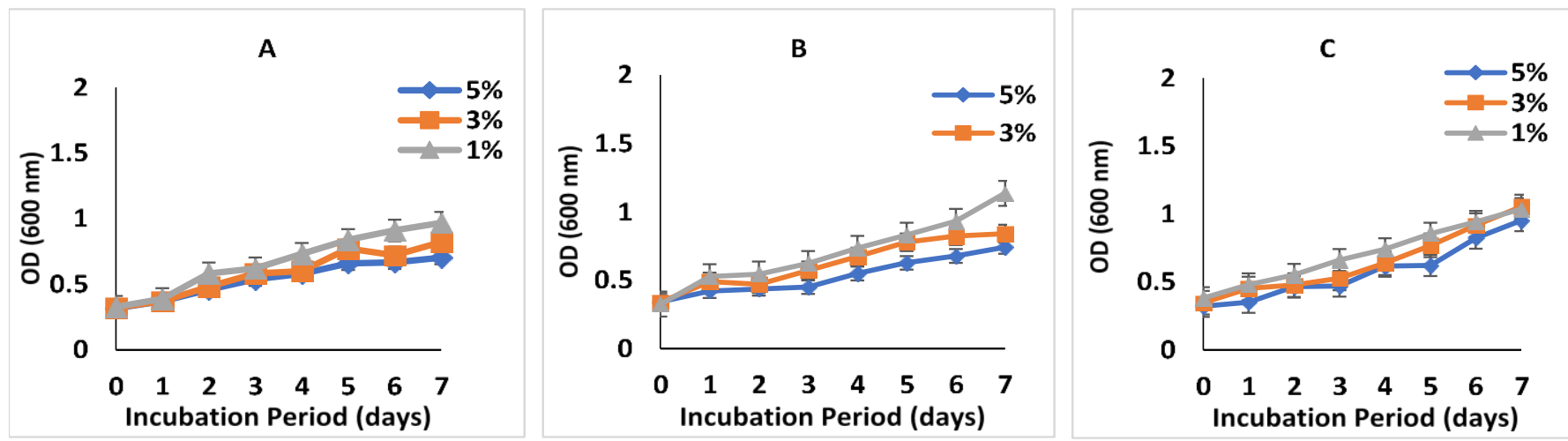

Fig. 5. Growth of test rhizobia isolated from pinto beans in presence of crude oil in the medium $(1-5 \% \mathrm{v} / \mathrm{v})$. Data represent means $\pm \mathrm{SD}(n=3) . \quad \mathbf{A}=R$. leguminosarum $\mathrm{N} 871 ; \mathbf{B}=$ B. diazoefficiens $\mathrm{USDA} 110 ; \mathbf{C}=B$. japonicum SEMIA5079.

bacteria isolated from leguminous plants nodules and roots cultivated in the rhizosphere soil of Acacia reported the presence of Ensifer meliloti (Sinorhizobium meliloti) in nodules of chickpea and common bean as $40.9 \%$, Rhizobium sp. in nodules and roots of common bean and lentil as $31.8 \%$, and Enterobacter sp. isolated in roots of faba bean, common bean, chickpea and lentil as $27.3 \%$ (Taoufiq et al. 2018).

The increasing in optical density of each test bacteria in the presence of crude oil indicates the survival and utilization of the oil for growth and degradation of the test hydrocarbon. The bacteria have strains that utilized the crude oil as a sole source of carbon and energy since there was no other source of carbon and energy. This Rhizobium responded to crude oil and showed increased optical density at the end of the seventh day. This means that the genes encoding each rhizobium were not inhibited by the crude oil hydrocarbons. These microorganisms are likely to possess enzymatic capacity to degrade the crude oil (Olukunle and Boboye 2013). Thus, increase in the hydrocarbon utilizing bacterial population conforms to the data from the work done by Lawson et al. (2012) and Ataikiru et al. (2018). Lawson et al. (2012) have reported that introduction of PHC into the soil encourages high microbial biomass. Joshi and Pandey (2011) also suggested that the percentage of petroleum utilizing bacteria in a particular environment appears to be an index of the presence of hydrocarbons in the environment. The bacteria might have broken the oil down into simple carbon compounds that are used to make the sugars, fat and proteins needed for growth and energy production ultimately the by-product become carbon dioxide and water (Okerentugba and Ezeronye 2003). This finding agrees with the report of Salam et al. (2011) that both Gram-negative and positive bacteria have been implicated in the mineralization of hydrocarbon pollutant. The dominance of Gramnegative bacteria in the samples agrees with that of Kaplan and Kilts (2004), that Gram-positive bacteria, when detected in bioremediation, are never diverse or dominant. The high moisture content of the oils might have provided the moisture necessary for bioactivity thus supporting the growth and survival of these microbes.

Reduction in OD of the oil medium at different incubation times could be due to possible disappearance of the crude oil in the medium due to exhaustion of the hydrocarbon which served as the carbon source for various metabolic activities. The difference in oil degradation ability of the rhizobia could be attributed to the difference in their genetic abilities in utilizing hydrocarbons as substrate vis-à-vis absorption, oxidation and environmental factors. Similar suggestion was made by Majid et al. (2008) and Onuoha et al. (2014) when they studied spent oil degradation with some bacteria. Rhizobia used in this research could play a vital role in plant nutrient cycling and replenishment in the soil. These microbes are also important for hydrocarbon degradation in soil. Their role includes the degradation and biotransformation of petroleum compounds into simple harmless compounds (Oluyege et al. 2011). Biodegradation by microbes is the key removal process of hydrocarbons which is controlled by physicochemistry, environmental conditions, 
bioavailability and the presence of catabolically active microbes (Stroud et al. 2007). One of the major challenges with phytoremediation is that it takes long time. Large-scale clean-up approach was applied to tackle the Deepwater Horizon oil spill in the USA, by direct delivery of a dispersant that boosted the natural biodegradation of the oil (Atlas and Hazen 2011). Also, studies have shown that a field-scale process of contaminated soil bioremediation is possible (Pelaez et al. 2013; Pizarro-Tobías et al. 2015).

\section{Conclusion}

In conclusion, this work has impacted the understanding and effectiveness of the crude oil degradative abilities of the isolated and tropical rhizobia species using their compactible legumes to degrade crude oil in soil. The use of plantassociated bacteria such as rhizobia to degrade toxic synthetic organic compounds in environment may provide an efficient, economic and sustainable bioremediation technology. This laboratory scale research study can also be applied on a large-scale study thus, are environmentally friendly and have been observed to promote the biodegradation of hydrocarbons. The results of this study showed that each test bacteria could survive and utilize crude oil at the percentages investigated. Thus, they will be useful to fixed nitrogen when added to (bioaugmentation and bio-stimulation strategies) the root of the pigeon peas and pinto beans planted in a crude oil polluted soil.

\section{Conflict of Interest}

The authors declare that they have no conflict of interest.

\section{References}

Ataikiru TL, Philip O, Chinedu C (2018) Bioremediation of Bonny light crude oil polluted soil by bioaugmentation using yeast isolates (Candida adriatica ZIM 2468 and Candida taoyuanica MYA-4700). Int. J. Environ. Res. Public Health 5: 52-61.

Atlas RM, Hazen TC (2011) Oil biodegradation and bioremediation: a tale of the two worst spills in U.S. history. Environ. Sci. Technol. 45: 6709-6715.

Boboye B, Olukunle OF, Adetuyi FC (2010) Degradative activity of bacteria isolated from hydrocarbon-polluted site in Ilaje, Ondo State, Nigeria. Afr. J. Microbiol. Res. 4:
2484-2491.

Cameron AG (2003). Lab Agnote No. C38, Lab Agnote, New York, $77 \mathrm{p}$.

Daniel IE, Nna PJ (2016) Total petroleum hydrocarbon concentration in surface water of cross river estuary, Niger Delta, Nigeria. Asian J. Environ. Ecol. 1: 1-7.

Diplock EE, Mardlin DP, Killham KS, Paton GI (2009) Predicting bioremediation of hydrocarbons: Laboratory to field scale. Environ. Pollut. 157: 1831-1840.

Eremrena, PO, Akonye LA (2013) Growth and biochemical performance of Cassava-Manihot esculenta Crantz to crude oil polluted soil amended with Centrosema pubescens Benth and NPK. J. Appl. Sci. Environ. Manag. 17: 195-201.

Fawole MO, Oso BA (2007) Laboratory manual of microbiology, Spectrum Book Limited Ibadan, Nigeria, pp. 15-22.

Gkorezis P, Daghio M, Franzetti A, Van Hamme JD, Sillen W, Vangronsveld J (2016) The interaction between plants and bacteria in the remediation of petroleum hydrocarbons: An environmental perspective. Front. Microbiol. 7: 1836

Gutierrez-Zamora M, Martinez-Romero E. (2001) Natural endophytic association between Rhizobium etli and maize (Zea mays L.). J. Biotechnol. 91: 117-126.

Ikuesan FA (2015) Bioremediation of selected agricultural soil samples contaminated with crude oil in Ondo State, Nigeria, Ph.D Thesis, The Federal University of Technology, Akure, Nigeria.

Inoni OE (2006) The effect of oil spillage on crop yield and farm income in Delta state, Nigeria. J. Cent. Eur. Agric. 7.

Ismail HY, Ijah UJJ, Riskuwa ML, Allamin IA, Isah MA (2014) Assessment of phytoremediation potentials of legumes in spent engine oil contaminated soil. Eur. J. Environ. Safe. Sci. 2: 59-64.

Joshi PA, Pandey GB (2011) Screening of petroleum degrading bacteria from cow dung. Res. J. Agric. Sci. 2: 69-71.

Kadali KK, Simons KL, Skuza PP, Moore RB, Ball AS (2012) A complementary approach to identifying and accessing the remediation potential of hydrocarbonoclastic bacteria. J. Microbiol. Meth. 88: 348-355.

Kaplan CW, Kitts CL (2004) Bacteria succession in a petroleum land treatment unit. Appl. Environ. Microbiol. 70: 1777-1786.

Larran S, Perello A, Simon M, Moreno V. (2002). Isolation and analysis of endophytic microorganisms in wheat (Triticum aestivum L.) leaves. World J. Microbiol. Biotechnol. 18: 683-686.

Lawson IY, Nartey EK, Darko DA, Okrah VA, Tsatsu D (2012) Microbial degradation potential of some Ghanaian soils contaminated with diesel oil. Agric. Biol. J. North Amer. 3: 1-5.

Lee K, Doe KG, Lee LEJ, Suidan MT, Venosa AD (2001) Remediation of an oil contaminated experimental freshwater wetland. Habitat recovery and toxicity reduction. In Proceedings of the 2001 International Oil Spill Conference, American Petroleum Institute, 
Washington DC.

Loiret F, Ortega E, Kleiner D, Ortega-Rodés P, Rodes R, Dong Z (2004) A putative new endophytic nitrogen-fixing bacterium Pantoea sp. from sugarcane. J. Appl. Microbiol. 97: 504-511.

Majid Z, Vossoughi M, Ardestani SK (2008) Naphthalene metabolism in Nocardia otitidiscaviarum stream TSHI, A moderately thermophilic microorganism. Chemosphere 72: 905-909.

Mallikarjuna N, Saxena KB, Jadhav DR (2011) Cajanus. In Chittaranjan, K. (Eds.), Wild crop relatives: genomic and breeding resources - legume crops and forages, Springer-Verlag, Berlin Heidelberg, pp. 21-33.

Mandal AJ, Sarma PM, Singh B, Jeyaseelan CP, Channashettar VA, Lal B, Datta J (2012). Metal polluted soils. biomanagement of metal-contaminated soils. Environ. Pollut. 20: 95-123.

Mohamed SH, Omran WM, Sadik AS (2014) Use of 16S rRNA gene for molecular identification of some bacteria isolated from soil in Taif having biochemical and antibiosis activities. Wulfenia 21: 173-185.

Nyananyo BL (2008) Global warming and its effect on the Niger Delta In Derefaka AA. Okorobia AM. (Eds.), History concourse 2007, Onyoma Research Publications, Port Harcourt, pp. 243-253.

Oberai M, Khanna V (2018) Rhizoremediation - Plant microbe interactions in the removal of pollutants. Int. J. Curr. Microbiol. Appl. Sci. 7: 2280-2287.

Odeny DA (2007) The potential of Pigeon pea (Cajanus cajan (L.) Millsp.) in Africa. Nat. Res. Forum. 31: 297-305.

Ogbogbodo IA, Azenabor UF, Osemwota IO (2005) Amelioration of crude oil polluted soil with poultry manure and effect on growth of maize and some soil properties. J. Plant Nutr. 28: 21-32.

Okerentugba PO, Ezeronye OU (2003) Petroleum degrading potentials of single and mixed microbial cultures isolated from rivers and refinery effluent in Nigeria. Afr. J. Biotechnol. 2: 288-292.

Olukunle OF, Boboye B (2013) The molecular succession of bacterial community of crude oil polluted soil and water samples from the Niger Delta Nigeria. Brit. J. Appl. Sci. Technol. 3: 777-788.

Oluyege JO, Odere JO, Kayode J (2011) Effect of organic manure on the aliphatic and aromatic compositions of diesel-oil contaminated soil. Ann. Sci. Eng. Technol. 1: 22-30.

Onojake CM (2004) Petroleum hydrocarbons and associated metals of Ebocha -8 oil spill polluted site in Niger Delta, Nigeria, M.Sc Thesis, University of Port Harcourt, Nigeria.

Onuoha SC, Chukwura EI, Fatokun K (2014) Stimulated biodegradation of spent lubricating motor oil in soil amended with animal droppings. Amer. J. Biol. Sci. 2: 1927.

Pandey P, Kang S, Maheshwari D (2005) Isolation of endophytic plant growth promoting Burkholderia sp. MSSP from root nodules of Mimosa pudica. Curr. Sci. 89: 177-180.

Pelaez AI, Lores I, Sotres A, Mendez-Garcia C, Fernandez-
Velarde C, Santos JA, Gallego JL, Sanchez J (2013) Design and field-scale implementation of an "on site" bioremediation treatment in PAH-polluted soil. Environ. Pollut. 181:190-199.

Pizarro-Tobías P, Fernández M, Niqui JL, Solano J, Duque E, Ramos JL, Roca A, (2015) Restoration of a Mediterranean forest after a fire: bioremediation and rhizoremediation field-scale trial. Microb. Biotechnol. 8: 77-92.

Quast C, Pruesse E, Yilmaz P, Gerken J, Schweer T, Yarza P, Peplies J, Glockner FO (2013) The SILVA ribosomal RNA gene database project: improved data processing and web-based tools. Nucleic Acids Res. 41: D590-D596.

Rauckyte T, Slawomir Z, Zenon P., Adekunle O. (2010) Determination of oil and grease, total petroleum hydrocarbons and volatile aromatic compounds in soil and sediment samples. J. Environ. Eng. Landsc. Manag. 18: 163-169.

Rodino AP, Santalla M, Montero I, Casquero PA, De Ron AM (2001) Diversity of common bean (Phaseolus vulgaris L.) germplasm from Portugal. Genet. Resour. Crop Evol. 48: 409-417.

Salam LB, Obayori OS, Akashoro OS, Okogie GO (2011) Biodegradation of Bonny light crude oil by bacteria isolated from contaminated soil. Int. J. Agric. Biol. 13: 245-250.

Stroud JL, Paton GI, Semple KT (2007) Microbe-aliphatic hydrocarbon interactions in soil; implications for biodegradation and bioremediation. Appl. Microbiol. J. 102: 1239-1253.

Tanee FBG, Akonye LA (2009) Effectiveness of Vigna unguiculata as a phytoremediation plant in the remediation of crude oil polluted soil for cassava (Manihot esculenta Crantz) cultivation. J. Appl. Sci. Environ. Manag. 13: 43-47.

Tanee FBG, Anyanwu DI (2007) Comparative studies of the growth and yield of two cassava lines (TMS 30572 and TMS 30555) in a crude oil polluted habitat. Sci. Afr. 6: $81-85$.

Taoufiq K, Faghire M, Tahrouch S, Nejmeddine M, Göttfert M, Oufdou K, Hatimi A (2018) Screening and molecular identification of endophytic bacteria isolated from legumes nodules and roots cultivated in Acacia rhizosphere soils collected in an arid region, Tata-Akka in south of Morocco. Indian J. Natur. Sci. 9: 14910-14919.

Thijs S, Sillen W, Rineau F, Weyens N, Vangronsveld J (2016) Towards an enhanced understanding of plantmicrobiome interactions to improve phytoremediation: engineering the metaorganism. Front. Microbiol. 7: 341.

Weyens N, Croes S, Dupae J, Newman L, van der Lelie D, Carleer R (2010) Endophytic bacteria improve phytoremediation of $\mathrm{Ni}$ and TCE co-contamination. Environ. Pollut. 158: 2422-2427.

Wokoma OAF (2014) Levels of total hydrocarbon in water and sediment of a polluted tidal creek, Bonny River, Niger Delta, Nigeria. Int. J. Sci. Technol. Res. 3: 351-354.

Yousaf S, Afzal M, Reichenauer TG, Brady CL, Sessitsch A (2011) Hydrocarbon degradation, plant colonization and gene expression of alkane degradation genes by endophytic Enterobacter ludwigii strains. Environ. Pollut. 159: 2675-2683. 